\title{
自動車用セラミックスの開発動向
}

\section{Development of "Car-ceramics"}

Shunzo Yamaguchi

1.は じめに

ファインセラミックスは，一般に熱的化学的に安定で あり，電気的にも優れた特性をもつことから，将来の新 素材として，各分野で注目されている.

近年，自動車用ガスタービンェンジンや自動車エンジ ン部品として，実用化の可能性が報告されるようになつ て，特に，世間一般の注目を集めるようになつた。時 に，世は鉄の時代から新石器時代に移りつつあるといわ れるほどになつている。

その注目を集めているセラミックスが，自動車用とし て使われた歴史は古い，数十年前，自動車の普及ととも に，ガソリンェンジンのスパークブラグの絶縁用碍子と してアルミナが既に使用されている。その後 1973 年の 石油危機と昭和 50 年 (1975 年) の排出ガス規制に対応 して排気系で使用される排気温センサーを初めとして, 多くのセラミックス部品が使われるようになつた.

ここでは，開発・実用化が進んでいるセラミックス部 品が自動車用として，どのように使われているかを日本 電装 (株) 関連品について紹介し，現实にセラミックス部 品の実用化が進展している様子を理解していただき，構 造用七ラミックスを主とする今後の開発動向について は, 各社の開発状況を含めてまとめ, 今後より多くの七 ラミックス部品が自動車部品として実用化されていくこ とを実感していただきたい。
2. 自動車用セラミックスとは

セラミックスは一般に,「熱処理によつて得られた非 金属の無機質固体」と定義される。また，七ラミックス は応用面より大別して，機能性七ラミックスと棈造用七 ラミックスに分けられる. 表題のけ動車用せラミックス は，自動車関連で使用されるといら慧味で用いられてお り，「カーセラミックス」と呼ばれることもある.

ここでカーセラミックスとして注目されるよらになつ たのは，排気規制対策部品として，触媒担体，排気温七 ンサー，酸素センサーなどが使用されるよらになつてか らである・

代表的な部品の歴史をあとめると Fig. 1 のよらにな る.これは日本電装における開発発完の時期をしめした ものであるが業界の動向とみなしてもよい.

その後, カーエレクトロニクスの普及とともに各種セ ンサーを導入し，燃費低減，商品性向上が㖕られてきて いる. 各種セラミックス部品の使用部署を Fig. 2 に 示す1).

これらはすべて一台の車についているわけではなく, 扣よその搭載位置をしめしている。材料としては，アル ミナ,フェライト, サーミスタからはじまり, 次にュー ジェライト，ジルコニアが使われ，最近になつて PZT, チタバリ半導体 $(\mathrm{PTC})$ ，窒化珪素などが使われるよう になつた。

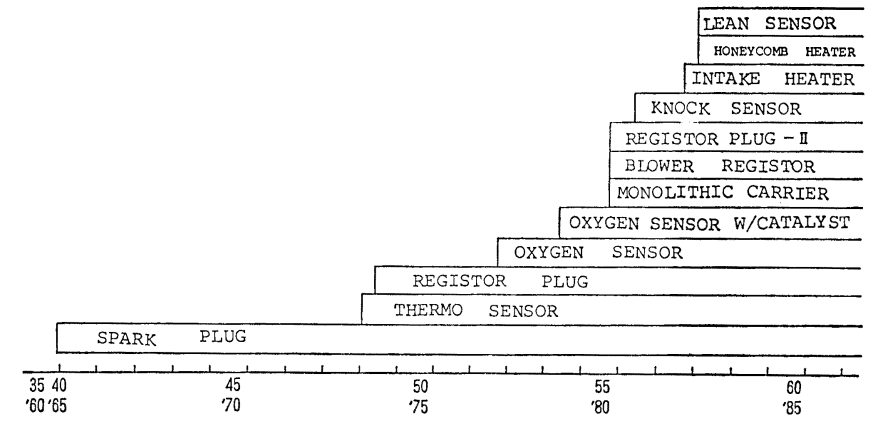

Fig. 1. Chronological development of car-ceramics components.

昭和 60 年 12 月 23 日受付 (Received Dec. 23，1985) (低頼解説)

* 日本電装(株)第 1 研究開発部研究主任 (Research \& Development dept., Nippondenso Co., Ltd., 1-1 Showa-cho Kariya Aichi pref. 448) 


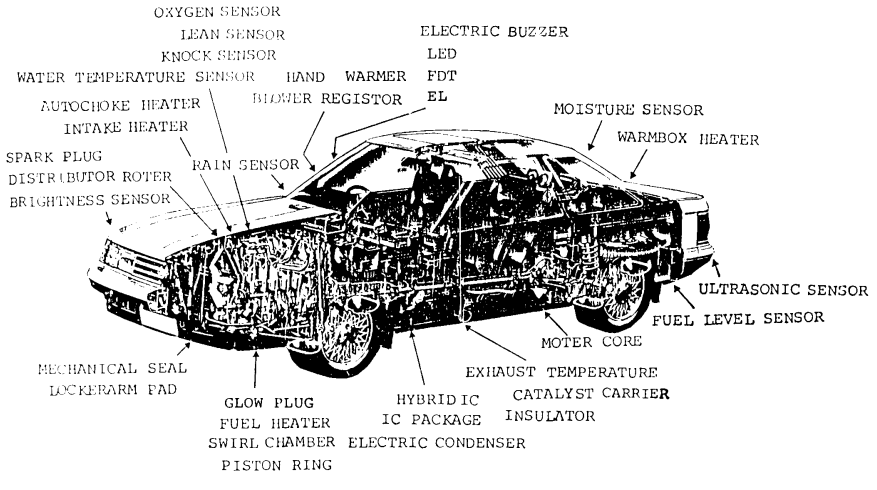

Fig. 2. Application of ceramic components to automobile').
Table 1. Material of car-ceramics (Functional).

\begin{tabular}{l|l}
\hline Thermo sensor & $\begin{array}{l}\mathrm{ZrO}_{2} \\
\mathrm{Cr}_{2} \mathrm{O}_{3}-\mathrm{Al}_{2} \mathrm{O}_{3}\end{array}$ \\
\hline Oxygen sensor & $\begin{array}{l}\mathrm{ZrO}_{2} \\
\mathrm{TiO}_{2}\end{array}$ \\
\hline $\begin{array}{l}\text { Knock sensor } \\
\text { Ultrasonic sensor }\end{array}$ & $\mathrm{PZT}$ \\
\hline Ceramic heater & $\mathrm{PTC}$ \\
\hline
\end{tabular}

\section{3. 機能性セラミックスの開発動向}

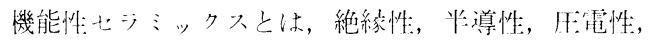
イオン伝洎俳などの性望をもつ七ラミックスで, その電 気的特性を利用するのでェレクトロ七ラミックスとも呼 ばれている. Table 1 に機能性七ラミックスの製品例と その材料を束上めて小寸。以下に代表的な製品を取り上 げセラミックスの特州, 情造, 他用例などを概説し自動 車用七ラミック久部品の研究開発の状況を理解していた だくことにする。

\section{$3 \cdot 1$ スパークプラグ}

スハークン゙ラグは, ガソリンェンジンの备シリンダ八 ッドに取りつけられ， $1000^{\circ} \mathrm{C}$ 以上, $45 \mathrm{~atm}$ 以上の然 焼ガスにさらされ，約 $10 \sim 20 \mathrm{kV}$ の高電日゙が加わる. これを渾足するために, 倡子はアルミナ七ラミックスを 使用している.ターボ車の出現, 軽量化などから, 小型 プラグ，突出しブラグなどの特殊形状プラグが増加し， スハークブラグの倡子に対する要求もきつくなり，材料 改良も必献七なつてくると思われる。

\section{$3 \cdot 2$ サーモセンサー}

排気規制に刘忘して, 酸化触媒が使用され, ての触媒 の温度検出用上して，サーモセンサーが使用されるよう になつた。サーモセンサーには高温サーミスタが使用さ れている.サーミスタ材料としては, 高温用には $\mathrm{ZrO}_{2}$ 系, $\mathrm{Al}_{2} \mathrm{O}_{3}-\mathrm{Cr}_{2} \mathrm{O}_{3}$ 系をた体としたものが多いがここで は $\mathrm{Al}_{2} \mathrm{O}_{3}-\mathrm{Cr}_{2} \mathrm{O}_{3}$ 系を用いている22. サーモセンサーは, 自動車の触媒装犆に使用されるために, 温度, 振動, 雾 囲気，熱衝撃などの使用環境条件を十分に考慮して，

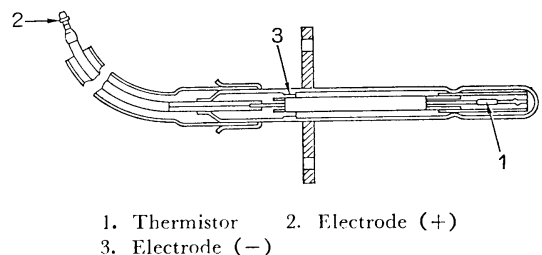

Fig. 3. Thermo sensor ${ }^{2}$.

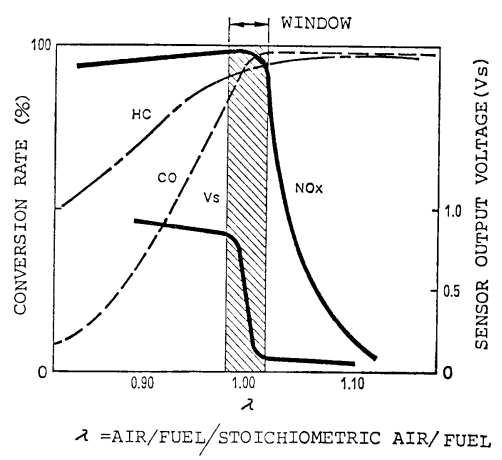

Fig. 4. Catalyst performance and property of oxygen sensor ${ }^{2)}$.

Fig. 3 に示すよらな構造としサーミスタは耐熱金属チ ューブ内に固定されている.

\section{$3 \cdot 3$ 酸素センサー}

引き続き，排気規制が強化されたのに伴い，三元触媒 を採用した排出ガス対策方式がとられ，この方式に酸素 センサーが使用されるようになつた。

酸素センサーはエンジンの排出ガス中に取りつけら れ，排出ガス中の空気過剩率 ( $\lambda$ ) を判定するものであ る2). Fig. 4 は横軸に $\lambda$ をとり三元触媒浄化率を示し たもので, $\lambda=1.0$ 付近で $\mathrm{CO}, \mathrm{HC}, \mathrm{NO}_{x}$ 三成分すべ てが浄化される. システムは, 酸素センサーの出力によ り, この $\lambda=1.0$ の点にエンジンへ供給される燃料量を フィードバック制御するようになつている.

酸素センサーは Fig. 5 に示すよらに, $\mathrm{CaO}$ または 


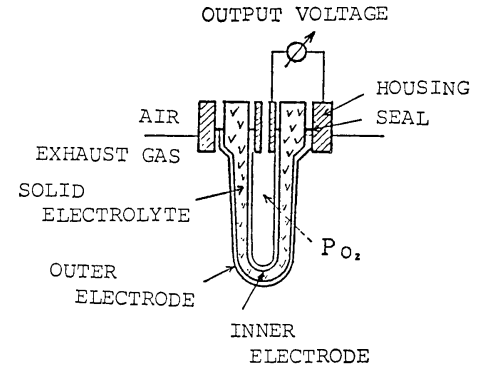

Fig. 5. Oxygen sensor ${ }^{2}$.

( cf)

OXYGEN SENSOR

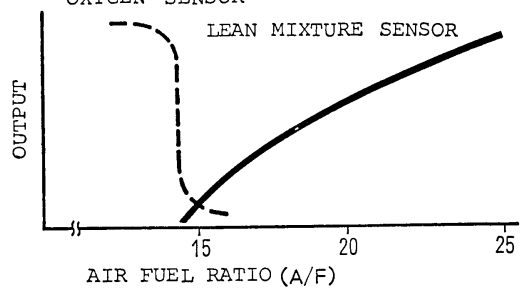

Fig. 6. Property of lean mixture sensor ${ }^{3)}$.

$\mathrm{Y}_{2} \mathrm{O}_{3}$ で安定化された先端が閉じた円筒状の $\mathrm{ZrO}_{2}$ 固体 電解質と，その内外面につけられた内側電極と外側電極 とからなる.内側電極は大気に開放され，外側電極は排 出ガスに触れている．外側電極には被毒保護のため, 多 孔質コーティング層を設けている.内外電極面の酸素濃 度の差により，センサ一電圧が発生し，Fig. 4 に示す よらなZ形の電圧曲線がえられる。市る一定の基準電圧 を定め，信号の大小により，リッチか，リーンかを判定 する.

\section{$3 \cdot 4$ リーンミクスチャセンサー}

酸素センサーと同じ， $\mathrm{ZrO}_{2}$ 固体電解質を用いて，排 出ガス中の空気過剩率を検出するセンサーとして，リー ンミクスチャセンサーが最近, 開発実用化された3)4 . こ のセンサーの特性は, Fig. 6 に示すように, 空気過剩率 （空然比）の増加とともに，ほぼ直線に増加するように なつている．センサーの構成を Fig. 7 に示すが，從来 の酸素センサーと比べて，電流検出していること，ヒ一 ターを内蔵して素子を一定温度にしていること，コーテ ィング層の厚さなどがことなつている.

このリーンミクスチャセンサーを用い，エンジンの空 燃比を 22 程度にフィードバック制御することにより， 大幅な燃料消費の向上が達成されている.

な抏このリーンミクスチャセンサーには，アルミナ セラミックスをベースとし，金属ペーストを印刷焼成し たセラミックヒーターを用い, 高温用を可能としている.

\section{5 ノックセンサー}

圧電性セラミックスを応用したものとして，ノックセ

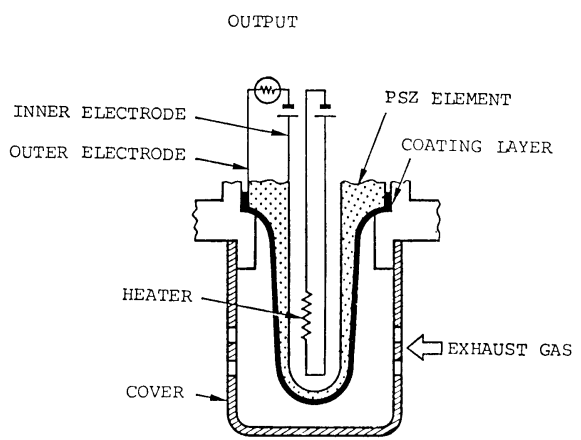

Fig. 7. Lean mixture sensor ${ }^{3)}$.

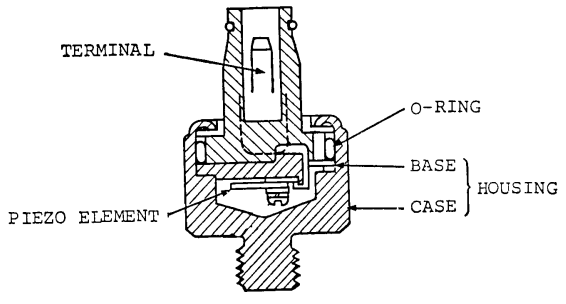

Fig. 8. Knock sensor ${ }^{5)}$.

ンサーがある5)。材料として，チタン酸・ジルコン酸鉛 (PZT) が使われている. 圧電性七ラミックスの上下面 に金属電極をつけ，力を加えると電圧が発生する.

ノックセンサーの構造の一例は Fig. 8 に示すよらで, 短冊状の圧電素子により，エンジンのノッキング時の小 さな機械振動（ライトノック）を検知する.

\section{6 超音波センサー}

ノックセンサーに使用される圧電性セラミックスの他 の応用例として，超音波センサーがある ${ }^{6)}$. これは後方 障書物感知装置として実用化されている.

超音波を送信あるいは受信する後方検知センサーの超 音波センサー部に $\mathrm{PZT}$ 圧電性セラミックスがつけられ る.

\section{7 セラミックヒーター}

PTG セラミックスは, 正の抵抗温度係数を持つサー ミスタで, $\mathrm{BaTiO}_{3}$ に微量元素を添加することにより, 半導体化し，キュリ一点を過ぎると筫常に抵抗が上昇す るもので, Fig. 9 に特性の一例を示す.この PTC 七 ラミックスをハニカム状とすることにより，放熱性が良 く，温度の立ち上がりの早い，また，自己温度制御でき るセラミックヒーターにでき，寒冷時のステアリングを 握つた手を暖めるクイックハンドウォーマーに使用され $3^{7) 8)}$.

またここ PTGハニカムは，放熱性の良いレジスタ 素子として，自動車空調用ブロアの保護用にも使用され ている. この他, PTC セラミックスは, 気化器直下の 
Table 2. Property of car-ceramics (Engineering).

\begin{tabular}{|c|c|c|c|c|c|c|c|}
\hline & $2 \mathrm{M} \cdot 2 \mathrm{~A} \cdot 5 \mathrm{~S}$ & $L \cdot A \cdot x S$ & $\mathrm{~K} \cdot \mathrm{A} \cdot \mathrm{M} \cdot \mathrm{S} \cdot \mathrm{F}$ & $\mathrm{Al}_{2} \mathrm{O}_{3}$ & $\mathrm{ZrO}_{2}$ & $\mathrm{Si}_{3} \mathrm{~N}_{4}$ & $\mathrm{SiC}$ \\
\hline $\begin{array}{l}\text { Density }\left(\mathrm{g} / \mathrm{cm}^{3}\right) \\
\text { Compressive strength }\left(\mathrm{kg} / \mathrm{mm}^{2}\right) \\
\text { Flexural strength }\left(\mathrm{kg} / \mathrm{mm}^{2}\right) \\
\text { Young's modulus }\left(\mathrm{kg} / \mathrm{mm}^{3}\right) \\
\text { Hardness }(45 \mathrm{~N}) \\
\text { Thermal expansion }\left(10^{-6} /{ }^{\circ} \mathrm{C}\right) \\
\quad \mathrm{RT} \sim 800^{\circ} \mathrm{C} \\
\text { Thermal conductivity } \\
\quad\left(\mathrm{cal} / \mathrm{cm} \cdot \mathrm{s} \cdot{ }^{\circ} \mathrm{C}\right) \\
\text { Specific resistance }(\Omega \cdot \mathrm{cm})\end{array}$ & $\begin{array}{l}2.5 \\
20 \\
7.0 \\
- \\
0.8 \\
0.003 \\
>10^{14}\end{array}$ & $\begin{array}{l}2.1 \\
23 \\
7.5 \\
0.51 \times 10^{4} \\
- \\
0.12 \\
0.0035 \\
>10^{14}\end{array}$ & $\begin{array}{l}2.6 \\
30 \\
11 \\
0.63 \times 10^{4} \\
- \\
11 \\
0.004 \\
>10^{14}\end{array}$ & $\begin{array}{l}3.95 \\
330 \\
55 \\
3.5 \times 10^{4} \\
88 \\
8 \\
0.065 \\
>10^{14}\end{array}$ & $\begin{array}{l}5.5 \sim 5.9 \\
-60 \sim 100 \\
1.5 \sim 10^{4} \\
85 \\
11 \\
0.004 \\
>10^{10}\end{array}$ & $\begin{array}{l}3.2 \\
65 \sim 100 \\
3.3 \times 10^{4} \\
87 \\
2.9 \\
0.037 \\
>10^{14}\end{array}$ & $\begin{array}{c}3.2 \\
\frac{45}{45} \\
4.5 \times 10^{4} \\
92 \\
4.4 \\
0.158 \\
10^{3} \sim 10^{6}\end{array}$ \\
\hline
\end{tabular}

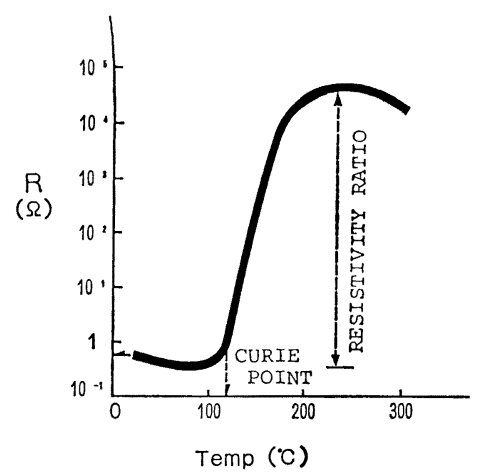

Fig. 9. Resistivity vs. temperature ${ }^{7) 8)}$.

ヒートライザ部につけられ, ェンジン暖気始動時の吸気 (混合気) 加熱にも使用されている.

以上，機能性七ラミックスの開発例について見てきた が，カーエレクトロニクスの発展に伴い, 上記した以外 にも各種センサー, アクチュエータが必要となつてきて いる.これらに対しても、ニューセラミックスが大きな 役割を果たしていくものとおもわれる.

現在, 話題となつているセンサーとしては, $\mathrm{NO}_{x}$ セ ンサー, 日射センサー, COセンサー, 湿度センサー, スモークセンサーなどがあり，近い将来実現するものと 考兄られる。また，これら多くのセンサー機能を一つの 素子に集約する多機能化や, 薄膜化による小型化などが 今後の開発方向であろら.

\section{4. 構造用セラミックス}

以上見てきた機能性の他に，七ラミックスの持つ特性 として, 耐熱性, 低熱膨脹性, 低熱伝導性, 高温高強度, 高硬度, 耐摩耗性, 低比重, 化学的安定性などがありこ れら特性を活かした応用に使われるものを構造用セラミ ックスと称し，この構造用セラミックスの自動車部品へ の応用も数多く考えられている. 以下 Table 2 に構造 用七ラミックスとして知られるセラミックスの特性をま とめて示す. 以下，その開発検討例について記述する.

\section{$4 \cdot 1$ 触媒担体}

構造用 ヒラミックスとして，使用実績あるものにま
ず，解媒担体がある・この触媒担体は触媒物質が担持さ れ，排出ガス中に配置されるものである.

このらち，モノリス・八ニカム触媒担体は9 ${ }^{9)}$ ，小型， 軽量にできること，触媒コンバーターにした特に，構造 が粒状担体の場合に比べ簡単にできることなどにより， 特に自動車用として，新たに開発されたものであり，特 殊な金型を用いた押出成形法により一体的に製作され 万.

主原料として，粘土鉣物のカオリン，タルクを用い， 有機バインダと水を加え，押出成形し，焼成することに より，コーディエライト組成 $\left(2 \mathrm{MgO} \cdot 2 \mathrm{Al}_{2} \mathrm{O}_{3} \cdot 5 \mathrm{SiO}_{2}\right)$ の焼成物が得られる， $25^{\circ} \mathrm{C} \sim 1000^{\circ} \mathrm{C}$ の平均の熱膨脹係 数が $0.7 \sim 1.0 \times 10^{-6} /{ }^{\circ} \mathrm{C}$ といら非常に小さな熱膨脹性 を示し，自動車排気系へ装着した時の熱衝撃にも十分甪 えられるものとなつている。

\section{$4 \cdot 2$ ディーゼルエンジン部品}

構造用セラミックスは，エンジン本体やェンジン直近 の部品にも使用が期待されており，これはガソリンェン ジンにたいしてよりもディーゼルエンジンに対して検討 されている.

七ラミックスの応用が期待される部品としては，然焼 室部品, 動弁系部品, ターボチャージャ部品がある.

一例として，力ミンズ社の低摩擦・斨熱ディーゼルエ ンジンがある(10).これは軍用車両を目的として, エンジ ン燃焼室まわりを, 部分安定化ジルコニア (PSZ) によ りセラミックス化して断熱し，高温となつた排気のエネ ルギーを,ターボコンパウンド化により, 回収し, 燃費 を改善するよらになつている. 効果は然費が改善される こと，粗覀然料での運転が可能になることなどがある. 他にも, 米国, 西独などの大学・企業の研究所でセラミ ックエンジンの検討を行つている例は多いが，いずれも 基礎段階のようである.

国内でも，各社でセラミックスを使つたディーゼルエ ンジンを検討しており，実機運転できることも報告され ているが，エンジン性能上の効果などはいまだ明確にさ れていない。

\section{3 副燃焼室}

実際にディーゼルェンジンに適用し，市場に登場した 
例としては，渦流室型エンジンの副燃焼室をセラミック ス化したものがある・トヨタ自動車といすず自動車が， 個別に開発実用化しているが，共に $\mathrm{Si}_{3} \mathrm{~N}_{4}$ 製であり，エ ンジン部品として $\mathrm{Si}_{3} \mathrm{~N}_{4}$ が実用化されたのは，画期的 な出来事といつても良い。他に， $\mathrm{Si}_{3} \mathrm{~N}_{4}$ を用いたセラミ ックグロープラグの例もあり，非酸化物セラミックスの 活用例の一つとして興味深い.

また，セラミックス焼結体ではないが，他の七ラミッ クスの応用例として，七ラミックファイバーを用いた金 属系複合材料を使用したセラミックファイバー合金強化 ピストンがトヨタ自動車において開発され量産採用され ている11).

このように一部の部品ではあるが，実際にセラミック スを用いた部品が量産エンジンに採用されたことは，今 後, 構造用セラミックスのエンジン部品への使用桩大が 急速に進むことを期待させる。

\section{4 ターボチャージャロータ}

セラミックスの適用が期待される他の部品としては, ターボチャージャロ一タがある.ターボチャージャロ一 夕は，現在，特殊合金製のものが使用されているが，高 温の排出ガス中で使用でき，かつ軽量化により応答性を 良くできるため，ロータのセラミックス化が各社で検討 されている.

フォルクスワーダン社に打いてセラミックターボチャ ージャロータを $1.5 \mathrm{~L}$ ディーゼルエンジンで評価した 結果，金属製に比べ応答性が向上したことが報告されて いる(2).

国内各社においても，盛んに開発が進められており， 各種展示会においても，多くのサンプルが展示されて扮 り, 束た, 最近, 日産自動車からセラミックターボチャ ージャロータ付車が発売されている.

\section{5 ガスタービンエンジン部品}

ディーゼルェンジン以上にセラミックス部品の開発が 期待されるェンジンとして，ガスタービンェンジンがあ る.ガスタービンェンジンの場合には，然焼ガスのタ一 ビン入口温度が高くなれば，エンジンの熱効摔の向上が 期待できる.

金属タービンブレードであれば，タービン入口温度を $1000^{\circ} \mathrm{C}$ 以上にはできないが，七ラミックスとすること により，1200`C 以上にすることができれば，熱効率を $30 \%$ 以上向上できる.

ガスタービンエンジンへのせラミックスの採用につい ては，米国において，国家プロジェクトであるAGT計 画などがあり，現在，モデルェンジンが完成しプロジェ
クトとしでの目標はほぼ達成し，长用化の可能性も高く なつているよらである。

使用されているセラミックスとしては， $\mathrm{SiC} か ゙$ 主で, $\mathrm{Si}_{3} \mathrm{~N}_{4}, \mathrm{ZrO}_{2}, \mathrm{MAS}, \mathrm{LAS}$ なども部品によつては採用さ れている.

国内各社も自動車用ガスタービンエンジンのセラミッ クス化の開発を進めているよらであるが，小型であるの で，七ラミックス化には，米国の場合よりか觉つて有利 と考光られている.

\section{5. おわりに}

以上，白動車用七ラミックスについて見てきたよ5 に，機能性セラミックスについては，すでに多くのもの が実用化されて括り，今後も引き続き，新製品が開発さ れていくものと思われる。構造用セラミックスに関して は，エンジン部品としての大きな期待がかけられなが ら，本格的な实用化には，まだ若「の时䦥がかかりそら である・

今後の自動東へのニーズとしては
A. 省凟源・省エネルギー
B. 安全. 無公青
C. 商品性向上

などがあげられるが，これに艮くマッチした製品をタイ ミング良く供給する必要が女る。

なお例としてあげた各種部品の開発は日本留装(株)七 ラミック技術部の手によるものが多いが，開発に当たつ てはトヨタ自動車並びに㤟田中央研究所の関係各位の御 援助をいただいた。

\section{交献}

1) 䅄田正俊：ファインセラミックス (1985), p. 79

2) 黄木正美: 七ラミックス, 17 (1982) 1, p. 21

3) 小林伸行, 赤塚隆夫, 中野次郎, 本杉勝浐: 自動 車技術，38(1984) 9，p. 1130

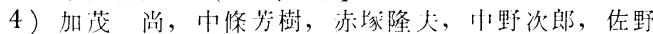

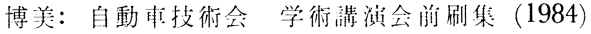
842 , p. 285

$5)$ 太田淳, 加茂 尚: 七ラミック久, 17 (1982 1, p. 30

6 ）デンソ一技報 (1984) 3 ，p. 8

7 ) 神保泉二, 渡辺忠清：们動本技術，38 (1984), p. 1254

8 ) デンソ一技報 (1984) 10, p. 2

9 ）土井啨夫：せラミックス， 17 (1982) 1, p. 25

10) 大橋正炤：工栄材料， 31 (1983) 12, p. 98

11) 堂了本忠：门動本技術，37 (1983) 8, p. 884

12) 岡野 弘：七ラミックス, 18 (1983) 1, p. 33 